\title{
Reproductive traits and spawning activity of striped eel catfish (Plotosidae) in Kolono Bay, Indonesia
}

\author{
ASRIYANA ASRIYANA ${ }^{*}$, HALILI HALILI \\ Department of Aquatic Resources Management, Faculty of Fisheries and Marine Sciences, Universitas Halu Oleo. Jl. H.E.A. Mokodompit, Kampus \\ Bumi Tridharma Anduonohu, Kendari 93232, Southeast Sulawesi, Indonesia. "email: asriyana@uho.ac.id
}

Manuscript received: 23 May 2021. Revision accepted: 29 June 2021.

\begin{abstract}
Asriyana A, Halili H. 2021. Reproductive traits and spawning activity of striped eel catfish (Plotosidae) in Kolono Bay, Indonesia. Biodiversitas 22: 3020-3028. Reproduction is a natural process for a species to ensure its sustainability in nature. This study aimed to investigate the reproductive traits and spawning activity of the striped eel catfish in Kolono Bay, South Konawe District, Southeast Sulawesi, Indonesia. A total of 965 individuals were collected monthly from June 2020 to May 2021 by using bottom experimental gillnets. Spent/spawning stages of the male and female fish were found during the East season (June-August). The proportions of the spent/spawning stages of male and female fish were $60 \%$ and $55.56 \%$ and the values of the gonadal somatic index were $1.19 \pm 0.53$ and $2.19 \pm 3.47$, respectively during the East season, indicate occurring the peak spawning in this season. Females matured gonads more rapidly at $198.3 \mathrm{~mm}$ compared to males at $224.5 \mathrm{~mm}$. Female fecundity was $1,730 \pm 390$ eggs, with an egg diameter of about 0.11-1.35 mm. Striped eel catfish is a total spawner fish that has one mode of egg distribution pattern. During the East season, it needs protection for spawning. The findings will help in designing effective management and developmental strategies to conserve the striped eel catfish population in the future.
\end{abstract}

Keywords: Conservation, fecundity, gonadal maturity, length at maturity, spawning period

\section{INTRODUCTION}

Striped eel catfish, Plotosus lineatus (Thunberg, 1787), known as marine catfish or sembilang, is a preferred catch. In Asia, local fishermen often capture the Plotosus genera because they have a higher commercial value as reported in several countries (Ahmed and Haque 2007; Usman et al. 2013a; Amornsakun et al. 2018; Thu et al. 2019). Typically, the striped eel catfish occupy the coral reefs, estuaries, intertidal areas, and open waters. This fish is widespread in the Western Indo-Pacific region: the west and south coasts of India and outside of Sri Lanka, eastward along the shores of Bangladesh and Myanmar, through the Indo-Australian Islands and the Philippines to Papua New Guinea (Gomon 1984). It also can be found in Rea Sea and East Africa to Samoa, Palau and Yap in Micronesia (Myers 1991); sometimes enters freshwaters of East Africa (Lake Malawi) and Madagascar (Taylor and Gomon 1986); in the Mediterranean (Doğdu et al. 2016).

The gray eel catfish, Plotosus canius (Hamilton, 1822), is a close relative of $P$. lineatus, which has gained a threatened status in several locations including India, Bangladesh, and Malaysia (Patra et al. 2005; IUCN Bangladesh 2000; Usman et al. 2013a), and this condition is potentially to occur in $P$. lineatus. To conserve the striped eel catfish population, there is an immediate need for practical data on its reproductive biology to design effective strategies.

The number of studies on striped eel catfish is lesser than that on gray eel catfish. Previous studies have focused on the growth (Ya et al. 2015); risk assessment (Galanidi et al. 2019); population dynamics (Asriyana et al. 2020a); and bycatch of Plotosidae (Asriyana and Halili 2021); whereas studies on reproductive biology are relatively limited (Vijayakumaran 1997; Heo et al. 2007). As part of reproductive traits and spawning activity, information on gonadal somatic index or maturity index (GSI), maturation age, fecundity, and spawning pattern is very important. Gonadal development can be quantitatively known through the GSI. Fluctuations of GSI values are closely related to the egg development stage, egg diameter, and ponderal index (Lizama and Ambrósio 2002; Tzikas et al. 2007; Asriyana and Halili 2020). This information is closely related to the management of fish as a water resource.

The response of aquatic biota to water bodies depends on the physical and chemical characteristics of the water bodies and is expected to give different responses to the reproductive biology of striped eel catfish in Kolono Bay. Many studies have reported that differences in fish responses are related to water conditions at different locations (Barbosa et al. 2018; Asriyana and Irawati 2019; Teixeira et al. 2019). This study investigated reproductive traits and spawning activity of striped eel catfish, $P$. lineatus, in Kolono Bay. The findings of this study could be beneficial in the conservation efforts of $P$. lineatus in different water bodies.

\section{MATERIALS AND METHODS}

\section{Sampling sites}

The Kolono Bay is located in South Konawe District, Southeast Sulawesi, Indonesia. The coordinates of the 
Kolono Bay are $4^{\circ} 20^{\prime} 35^{\prime \prime}-4^{\circ} 27^{\prime} 30^{\prime \prime} \mathrm{S}$ and $122^{\circ} 39^{\prime} 55^{\prime \prime}-$ $122^{\circ} 47^{\prime} 49^{\prime \prime} \mathrm{E}$ (Figure 1). The observation station is located horizontally. Station I, which is bordered by mangrove ecosystems and coral reefs, has substrate rock type and coral fragments and it is located adjacent to the river mouth. Station II and III, bordered by seagrass, mangrove, and coral reef ecosystems, have a different substrate, muddy sand substrate and rocky substrate type. Station III, located around the bay mouth. The selection of the station aims to ensure that the striped eel catfish samples caught represent the condition of the striped eel catfish population in the waters of Kolono Bay.

\section{Sampling design}

Sampling was conducted every month for 12 months in all stations from June 2020 to May 2021. The study is included four seasons: East season (June to August), EastWest season (September to November), West season (December to February), and West-East season (March to May). Fish were caught using bottom experimental gillnets, with net meshes of $1.25,1.5,1.75,2$, and 3 inches. The length and height of the net used for each mesh are 80 and $1.5 \mathrm{~m}$ in the water. The nets are installed at high tide and removed at low tide.. During fishing, water quality parameters, such as turbidity, salinity, $\mathrm{pH}$, and temperature were measured at each station. Turbidity, salinity, $\mathrm{pH}$, and temperature were measured in-situ using a turbidity meter (WGZ-1B Portable Digital), hand refractometer (ATAGO), pH meter (Hanna Digital HI 98107), and Hg thermometer, respectively.

Fish were identified according to the method of Froese and Pauly (2020). The total length ( $\mathrm{mm}$ ) and weight (g) of the collected samples were measured and the gonads were collected after the opening of the abdominal cavity of the fish. The sex of fish was distinguished based on gonadal morphology and the presence of genital papillae in the abdomen (Figure 2). The gonads were weighed using a $0.01 \mathrm{~g}$ scale, followed by analyzing the gonadal somatic index (GSI) and fecundity.
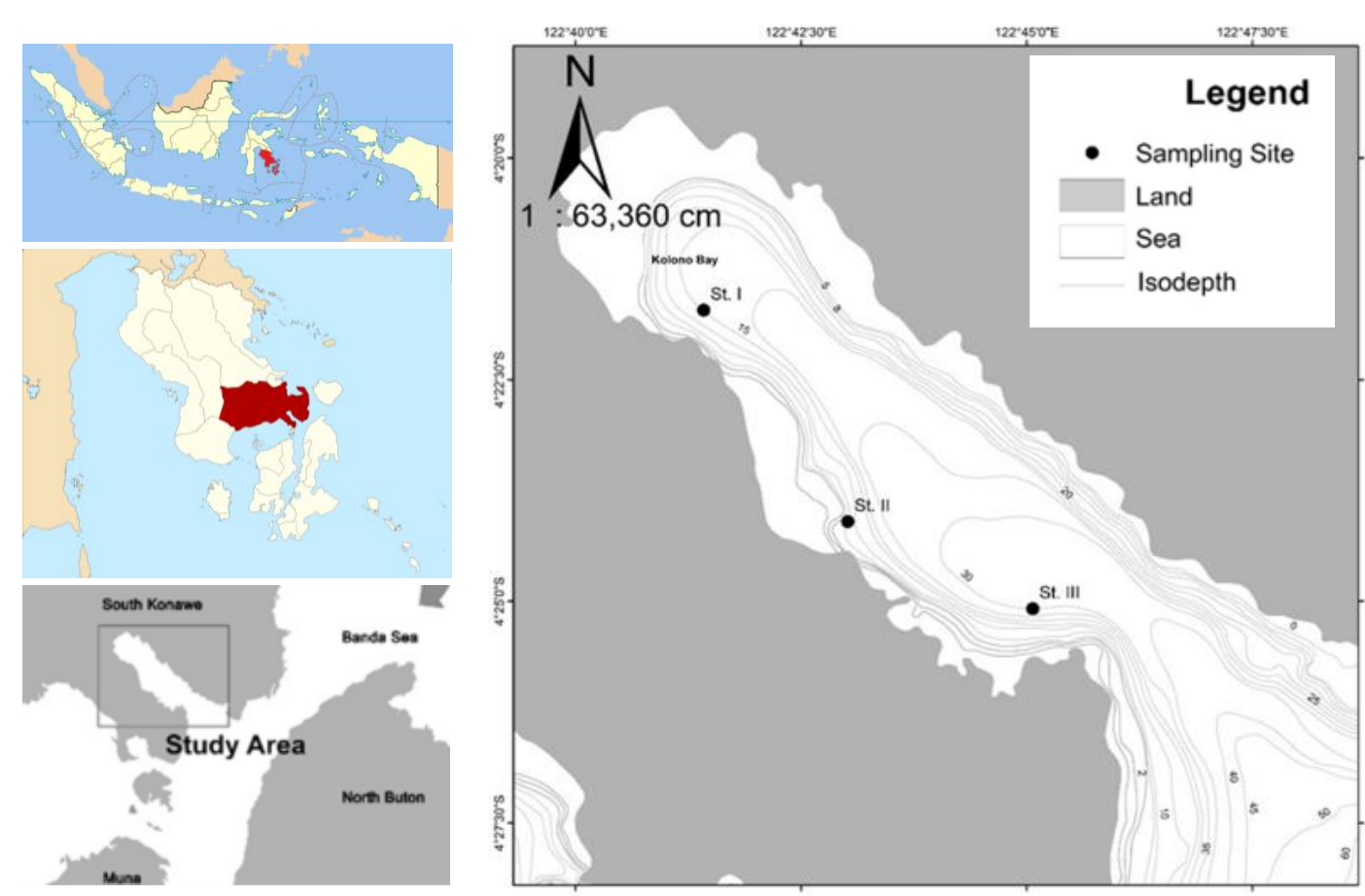

Figure 1. Location of the study in Kolono Bay, South Konawe District, Southeast Sulawesi, Indonesia from June 2020 to May 2021
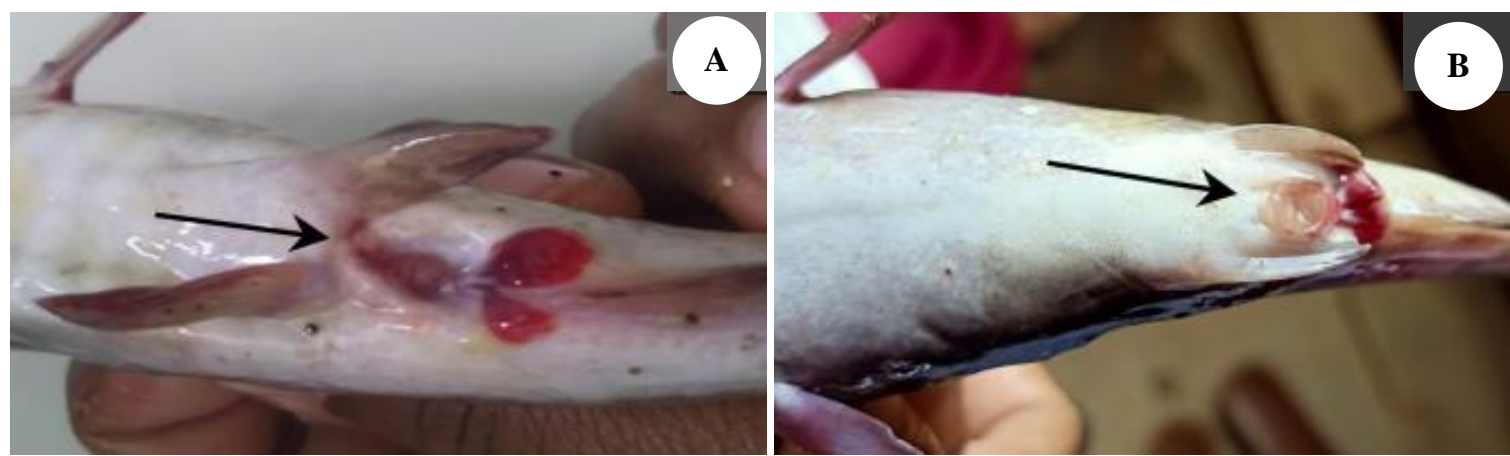

Figure 2. Sexual dimorphism of striped eel catfish. A. Male; B. Female 
The eel catfish sex ratio was determined by assessing the number of male and female fish, according to the methods of Usman et al. (2013a). Observation of gonads was carried out on fish that had undergone the stage of gonad maturity based on Heo et al. (2007). Gonadal fish development was determined based on the method of Heo et al. (2007), wherein the stages of gonad development of male and female fish are categorized into six stages: early growing, growing, early mature, mature, spent/spawning, degenerative and recovery stages. The GSI was determined by comparing the gonadal weight with the bodyweight of the fish (Adebiyi et al. 2011; Freitas and Montag 2019). Length at maturity was determined by plotting a graph of the percentage of mature gonad fish versus its total length. Minimum fish length of at least $50 \%$ of mature gonad fish (mature and spent/spawning stage) is stated as the size of the first mature gonad fish (King 1995; Khan et al. 2002). Striped eel catfish spawning time was determined based on variations in GSI values. Fecundity was analyzed using gravimetric methods (Khan et al. 2002; Trueman 2006; Ahmed and Haque 2007). The spawning patterns were determined according to female fish egg size distribution in the early mature, mature, and spawning stages. The diameters of the eggs were determined by using an ocular micrometer (Amornsakun et al. 2018).

\section{Data analysis}

Differences in body length and weight between sexes were analyzed using the non-parametric Mann-Whitney U test, at a confidence level of $95 \%$. Differences in water quality parameters, sex ratio, GSI, and fecundity based on the season were analyzed using the non-parametric KruskalWallis test, at a confidence level of 95\% (Sokal and Rohl 1995). Data were analyzed with the SPSS ver. 26 software.
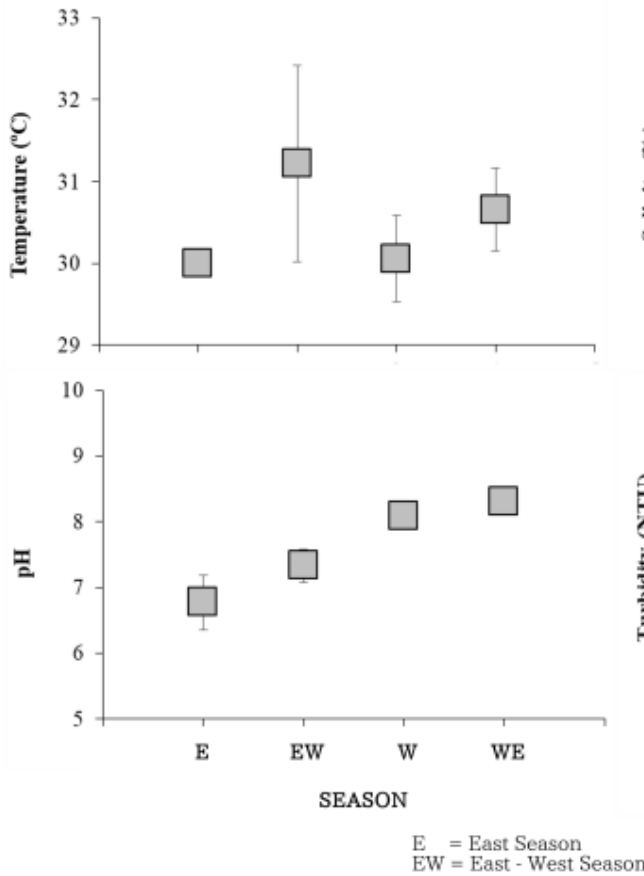

\section{RESULTS AND DISCUSSION}

\section{Physical and chemical conditions of the water}

At the time of this study, there were considerable variations in the physical and chemical conditions of the water (Figure 3). Temperature, salinity, and $\mathrm{pH}$ were significantly different between the seasons $(p=0.003$; $0.012 ; 0.000$, respectively; $\alpha=5 \%$ ), except for the turbidity $(p=0.142, \alpha=5 \%)$.

\section{Sex ratio, gonadal development, and length at maturity}

The total number of striped eel catfish caught in the water of the Kolono Bay was 965 individuals consisting of 713 males and 252 females. The length and weight of male fish ranged 40-325 $\mathrm{mm}$ and 0.3-218.2 $\mathrm{g}$, respectively. Whereas the length and weight of female fish ranged 40$254 \mathrm{~mm}$ and 0.3-123.4 g, respectively. The male striped eel catfish were more in number than the female counterparts, with a ratio of 2.82:1 (Table 1). According to the KruskalWallis test, the ratio of male-to-female fish did not differ in all seasons $(p=0.160, \alpha=5 \%)$.

The gonadal maturity stage is a certain stage of gonad development before and after the fish is spawning. The percentage of gonads that develop in striped eel catfish varies between seasons (Figure 4). In this study, gonad maturity stages were between early growing to spent/spawning stages, except for the degenerative and recovery stages. The spent/spawning stage in male and female fish populations was $60 \%$ and $55.56 \%$, respectively which only detected in the East season.
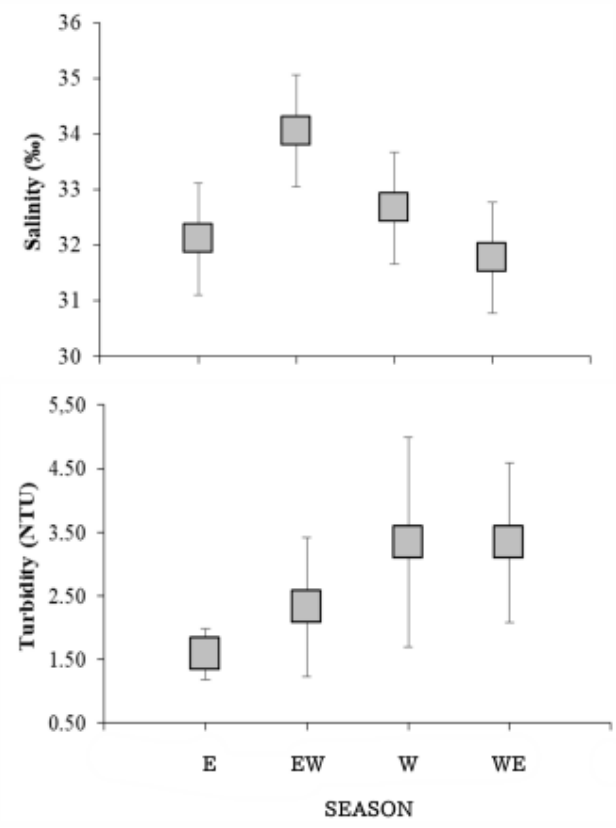

$\mathrm{W}=$ West Season

Figure 3. Seasonal physical and chemical variations in the waters of the Kolono Bay, South Konawe District, Southeast Sulawesi, Indonesia 


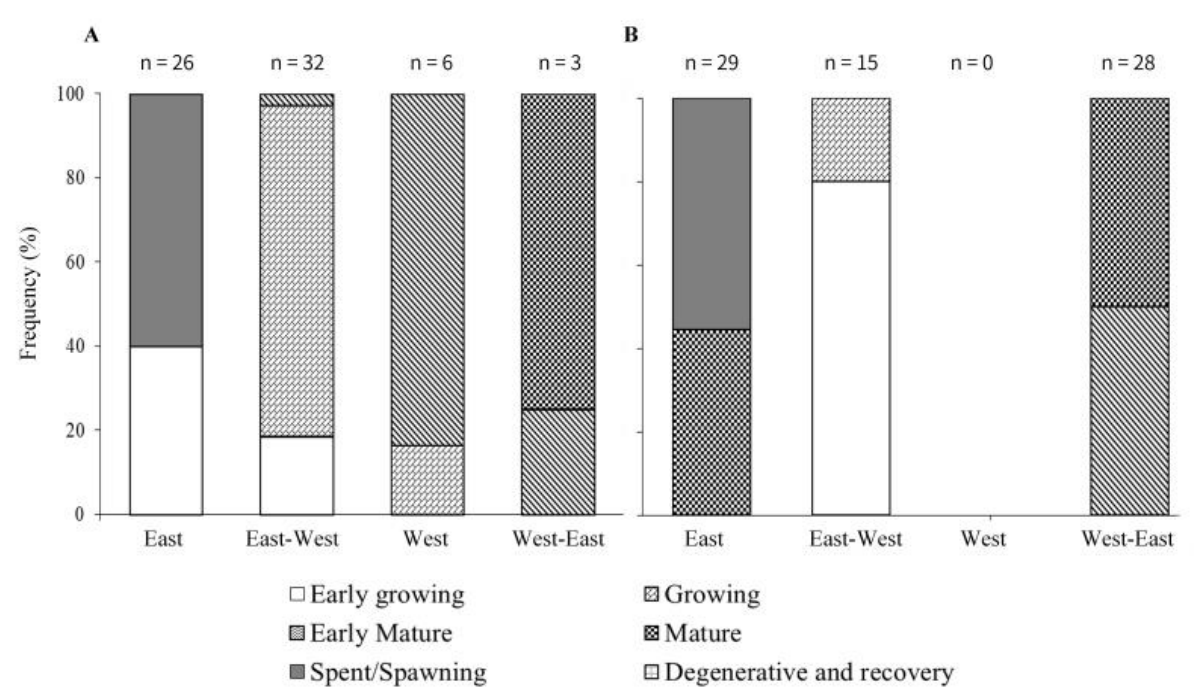

Figure 4. Seasonal variations of gonadal development of striped eel catfish in the Kolono Bay, South Konawe District, Southeast Sulawesi, Indonesia. A. Male; B. Female

Table 1. Seasonal variations in the sex ratio of the striped eel catfish in the Kolono Bay, Indonesia

\begin{tabular}{lccccc}
\hline \multirow{2}{*}{ Sex } & \multicolumn{4}{c}{ Season } & n \\
\cline { 2 - 5 } & East & $\begin{array}{c}\text { East- } \\
\text { West }\end{array}$ & West & $\begin{array}{c}\text { West- } \\
\text { East }\end{array}$ & \\
\hline Male & 387 & 279 & 6 & 41 & 713 \\
Female & 149 & 37 & 0 & 66 & 252 \\
Sex ratio & $2.62: 1$ & $7.34: 1$ & $1: 0$ & $1: 1.62$ & $2.82: 1$ \\
\hline
\end{tabular}

Note: $p>0.05(\alpha=5 \%, \mathrm{df}=3)$, the Kruskal-Wallis test

The high proportion of the male and female fish populations in the spent/spawning stage indicated that the spawning season for striped eel catfish occurs in the East season (June-August). During the West season, the number of striped eel catfish was limited. Only six male fish and no female fish were found in the West season.

The variations in the GSI values during the study period are presented in Table 2. The results indicated that the fish do not lay eggs simultaneously and, therefore, the gonadal development varies between the seasons $(p=0.000, \alpha=$ $5 \%)$. An increase follows the higher development of gonad-striped eel catfish in the value of GSI (Figure 5).

The highest GSI values were found for both male and female fish in the East season (June-August), implying occurring of spawning in this season. Latter conditions showed no difference from the high proportion of male and female gonad development during the spent/spawning stage that occurring in the East season. At the first maturity, length was 224.5 and $198.3 \mathrm{~mm}$ in male and female fish, respectively (Figure 6), suggesting that female fish mature earlier than male fish.

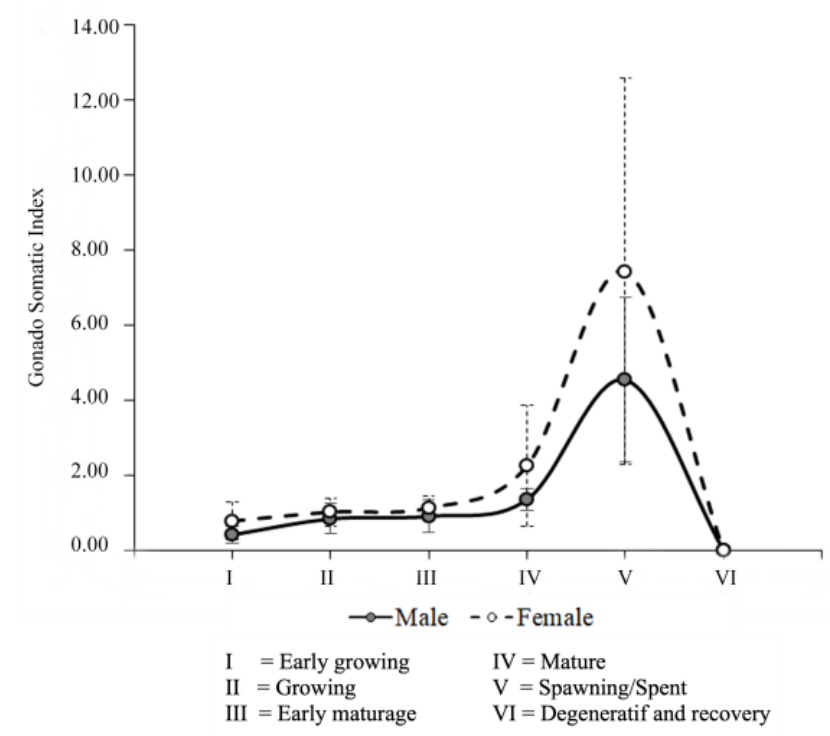

Figure 5. Correlation between gonadal development stage and gonadal somatic index of striped eel catfish in the Kolono Bay, South Konawe District, Southeast Sulawesi, Indonesia

Table 2. Seasonal variation of gonadal somatic index (GSI) of striped eel catfish in the Kolono Bay, South Konawe District, Southeast Sulawesi, Indonesia

\begin{tabular}{lccccc}
\hline \multirow{2}{*}{ Season } & \multicolumn{3}{c}{ Male } & \multicolumn{3}{c}{ Female } \\
\cline { 2 - 6 } & Range & Mean \pm SD & n & Range & Mean \pm SD \\
\hline East & $0.53-2.94$ & $1.30 \pm 0.38$ & 26 & $1.32-2.12$ & $1.55 \pm 0.38$ \\
East-West & $0.13-0.92$ & $0.56 \pm 0.17$ & 32 & $0.53-1.37$ & $1.01 \pm 0.26$ \\
West & $0.01-0.07$ & $0.05 \pm 0.03$ & 6 & 0 & 0 \\
West-East & $0.14-1.40$ & $0.58 \pm 0.71$ & 3 & $0.19-1.83$ & $0.75 \pm 0.47$ \\
\hline
\end{tabular}

Note: SD: standard deviation; $\mathrm{n}$ : number of individuals; $p<0.05(\alpha=5 \%, \mathrm{df}=3)$, the Kruskal-Wallis test 


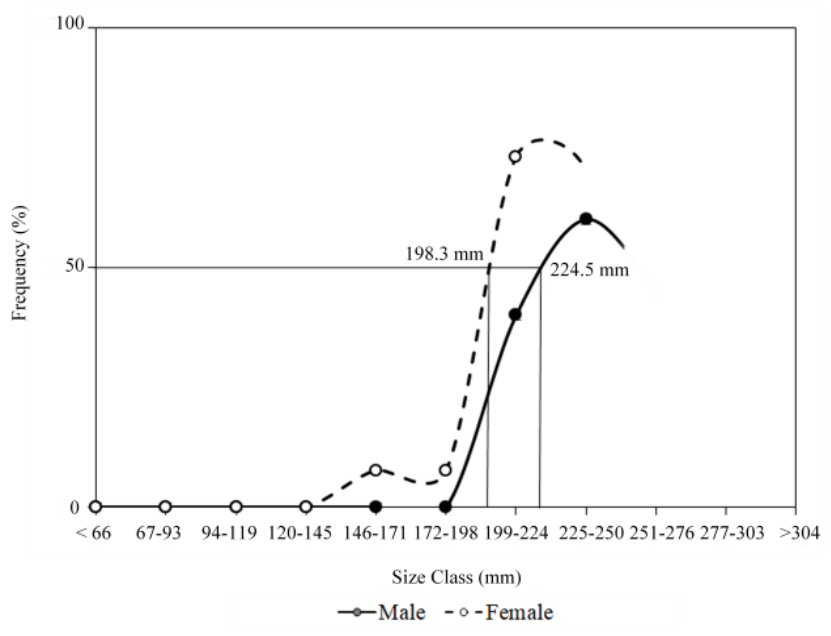

Figure 6. Length at first maturity (Lm50) of striped eel catfish in the Kolono Bay, South Konawe District, Southeast Sulawesi, Indonesia

Table 3. Seasonal variations in the fecundity of striped eel catfish in the Kolono Bay, South Konawe District, Southeast Sulawesi, Indonesia

\begin{tabular}{lccc}
\hline \multirow{2}{*}{ Season } & \multicolumn{2}{c}{ Fecundity } & \multirow{2}{*}{ N } \\
\cline { 2 - 3 } \multicolumn{1}{c}{ East } & Range & Mean \pm SD & \\
East-West & $1,415-2,194$ & $1,730 \pm 390$ & 29 \\
West & - & - & - \\
West-East & $995-1,800$ & $1,415 \pm 310$ & - \\
\hline
\end{tabular}

Note: $p<0.05(\alpha=5 \%, \mathrm{df}=3)$, the Kruskal-Wallis test

\section{Fecundity}

The total number of eggs produced by female fish during spawning (fecundity) is listed in Table 3. The amount of fecundity was significantly different between the seasons ( $p=0.002, \alpha=5 \%$ ), with the highest fecundity occurring from June to August, which was approximately 1,415-2,194 eggs. The relationship between the magnitude of fecundity and the total length and body weight of female fish are $\mathrm{F}=0.36 \mathrm{TL}^{1.61}\left(\mathrm{R}^{2}=0.61\right)$ and $\mathrm{F}=14.43 \mathrm{~W}+915.72$ $\left(\mathrm{R}^{2}=0.33\right)$, respectively.

\section{Spawning pattern (distribution of the egg diameter)}

According to the size, egg diameters were categorized into nine groups (Figure 7). The shift in the distribution of the egg diameter to the right implies that the greater the gonad maturity stage, the greater is the diameter of the egg.

\section{Discussion}

The Kolono Bay is a nursery ground by the juveniles of striped eel catfish male and female. The length and weight of the fish samples varied from 67 to $93 \mathrm{~mm}(43.25 \%$ to $47.62 \%)$ and $<20.4 \mathrm{~g}(80.56 \%$ to $81.63 \%)$, respectively. The Kolono Bay has complex ecosystems, such as seagrass, mangrove, and coral reef ecosystems. The three ecosystems are a habitat for protection, food foraging, and growth of marine life, as reported by Asriyana et al. (2020a) to striped eel catfish and other authors who performed studies in different locations (Verweij et al. 2006; Asriyana et al. 2018; 2020b).

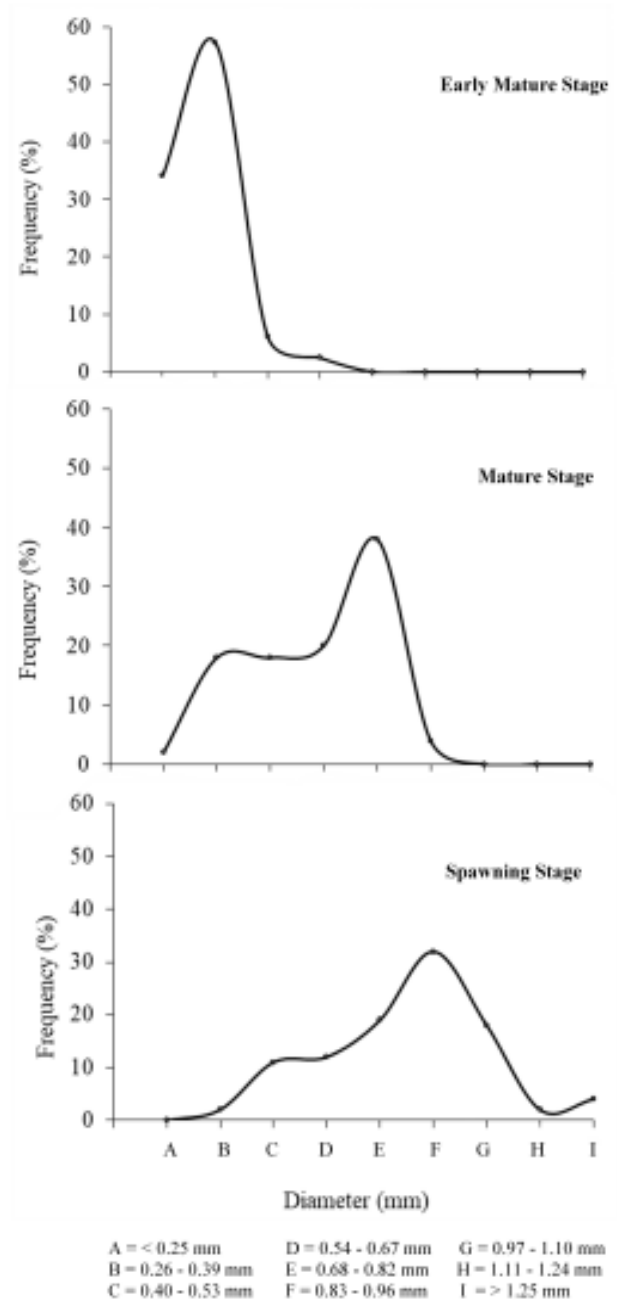

Figure 7. Egg diameter distribution of striped eel catfish in the Kolono Bay, South Konawe District, Southeast Sulawesi, Indonesia

The striped eel catfish demonstrated primary and secondary sexual characteristics, such as sexual dimorphism between the male and female fish; for example, the presence of urogenital papillae in the abdomen (Figure 2) which has been also found in gray eel catfish, $P$. canius (Amornsakun et al. 2018). These signs enable easier determination of the sex ratio of the population in the waters. In our study, the sex ratio of striped eel catfish was not significantly different between the seasons, with the proportion of male fish being higher than female fish (2.82: 1$)$.

At the beginning of life, the number of male fish was higher than female fish (East, East-West, and West seasons). However, toward the time of spawning, the number of females was higher than male individuals (Table 1). This difference might be related to the behavior of male fish. Just before the spawning season, adult male fish burrow and build nests under rocks and remain in the nests after spawning to deposit eggs (Thresher 1984). This behavior could be expected to cause an adult male for the captured in spawning time lower than adult females. Meanwhile, after laying eggs, more male individuals at the juvenile stage were found than adult males. The sex ratio 
information is important to know because it is related to the reproductive strategy developed by the eel catfish to support the success of the spawning process. The ideal sex ratio of male-to-female fish in a population is $1: 1$, that is, $50 \%$ male and 50\% female fish (Ball and Rao 1984). Spawning migration can cause deviations from the ideal sex ratio (Ilhan and Togulga 2007), where the genital ratio in the period leading up to and during spawning can change regularly. In the beginning, the male fish dominate, and then the sex ratio can change to $1: 1$, and followed by female fish dominance. These deviations can also be caused by environmental factors, including temperature, light, salinity, and the social environment of fish life (Jobling 1995); differences in fish distribution, activity, and movement (Türkmen et al. 2002); childcare activities (Liang et al. 2005); fishing mortality (Offem et al. 2008) and predation (Alp and Kara 2007); sex differences in growth, death, or reproductive energy costs (Araújo et al. 2019); and response to food availability. If food availability is abundant, female fish predominate, and vice versa (Vicentini and Araújo 2003).

Reproductive activities can be determined qualitatively based on gonadal development and quantitatively based on fluctuations in the GSI value. An increase in the development of gonad-striped eel catfish is always followed by an increase in GSI value (Figure 5). The higher the stages of gonadal development of striped eel catfish, the more variations in the GSI obtained, and then the GSI value will decrease when the spawning ends. Therefore, the GSI value can be used to determine the spawning season of fish (Figure 4). The presence of male and female individuals that include in the spent/spawning stage from June to August (East season) indicates the spawning season for striped eel catfish. These findings are in line with the high values of male and female GSI (1.19 \pm 0.532 and $19 \pm 3.47$, respectively). In addition to the phenomenon of male and female spawning fish (Figure 4), high GSI values (Table 2), peak spawning season of eel catfish are from the high value of the ponderal index in July ( $\mathrm{K}=1.27-1.29)$ and the presence of larvae in August (Asriyana et al. 2020a). Ponderal index is an index that represents fish fatness or the accumulation of fat and gonadal development if viewed from fish nutritional adequacy (Le Cren 1951; Asriyana et al. 2020a). Ponderal index value increases in the peak of the spawning season and decreases thereafter. During the spawning season, the gonads of the striped eel catfish are growing. Therefore, increases in the sperm size and egg diameter are reflected by elevated ponderal index and GSI values. After spawning, both values decrease because sperm and eggs decrease, further increasing the amount of energy expenditure for spawning (removing the eggs and sperm). This result is supported in the study by Heo et al. (2007) that was conducted in the waters of the Sungsan and Jocheon, Korea. According to histological observations and variations in the GSI values, $P$. lineatus seems to have a reproductive cycle consisting of several stages. These include male fish undergoing maturation during September-May and spent stage during April-July and female fish undergoing maturation during April-June and spawning stage during June-July. High GSI values have been reported during the spawning season for other catfish species, such as P. canius (Usman et al. 2013a) and Phractocephalus hemioliopterusus (Freitas and Montag 2019). Of the 965 individuals obtained during the study (713 males and 252 females), only 139 individuals (67 males and 72 females) could be analyzed for gonadal somatic index. This is related to the common gonadal development in fish, which includes two processes, namely the gonadal growth stage and the gonadal maturation stage as reported by Lagler et al. 1977; Harvey and Hoar 1979. The growth stage of fish gonads takes place from fish hatching to sexual maturity. While the gonad maturation stage takes place after the fish reaches adulthood and continues to develop as long as the fish's reproductive function is still running normally.

Some studies have demonstrated that fish from the family Plotosidae do not always have a spawning season from June to August (Table 4). Variations in environmental conditions cause changes in the spawning season, and the fish look for favorable conditions for the development of spawning yields. The temperature, salinity, and $\mathrm{pH}$ of the Kolono Bay water are different significantly in all seasons ( $p<0.05, \alpha=5 \%$ ), even during the East season (JuneAugust). The physical and chemical conditions of the waters (temperature, $30.00 \pm 00^{\circ} \mathrm{C}$; salinity, $32.11 \pm 2.08$ $\%$; and $\mathrm{pH}, 6.78 \pm 0.32$ ) were optimal to support the spawning activity of striped eel catfish. In several other fish species, the spawning season is influenced by the aquatic environment and food availability, migration tactics, and age structure (Yoneda and Wright 2015; Gallagher et al. 2018; Arula et al. 2019; Teixeira et al. 2019).

Table 4. Spawning season in several members of the family Plotosidae

\begin{tabular}{llll}
\hline \multicolumn{1}{c}{ Species } & Spawning period & \multicolumn{1}{c}{ Location } & \multicolumn{1}{c}{ References } \\
\hline P. canius & May-June & Hooghly-Matkah Estuary and Chilka Lake, India & Sinha (1984) \\
$P$. lineatus & October-January & North Andhra Pradesh coast, India & Vijayakumaran (1997) \\
$P$. canius & April-July & Coastal region of Khulna, Bangladesh & Khan et al. (2002) \\
P. canius & April-July & Bangladesh & Ahmed and Hague (2007) \\
$P$. lineatus $(\mathrm{M})$ & September-May & Sungsan and Jocheon coast, Korea & Heo et al. (2007) \\
$P$. lineatus $(\mathrm{F})$ & June-July & & \\
$P$. canius & October, April & Semarang, Indonesia & Dewanti et al. (2012) \\
$P$. canius & July-October & Pattani Bay, Thailand & Amornsakun et al. (2018) \\
$P$. lineatus $(\mathrm{M})$ & June-August & Kolono Bay, Indonesia & This research (2021) \\
$P$. lineatus $(\mathrm{F})$ & June-August & & \\
\hline
\end{tabular}


In striped eel catfish, the first mature gonad occurs more quickly in females than in male fish (Figure 6), suggesting that female fish gonads mature faster than male fish gonads, at $198.3 \mathrm{~mm}$ in size. In the Indian and Korean waters (Vijayakumaran 1997; Heo et al. 2007), the $P$. lineatus gonads have been reported to mature earlier, at 159 $\mathrm{mm}$ and $>150 \mathrm{~mm}$, respectively. The difference in size can be attributed to the differences in growth rates, food availability, and environmental conditions of the waters that support the growth of striped eel catfish. P. lineatus in the Kolono Bay had a lower growth coefficient of 0.27 per year. The maximum length $(251.89 \mathrm{~mm})$ of the fish was attained at 2.4 years of age (Asriyana et al. 2020a), whereas in Indian waters, the growth coefficient is more excellent at 1.37 per year and the fish reach a maximum length of up to $243.73 \mathrm{~mm}$ at 2.19 years of age (Vijayakumarn 1997). These findings demonstrate that $P$. lineatus in Indian waters has a higher growth rate and therefore reaches the gonadal stage at a faster pace than P. lineatus in the Kolono Bay waters. Several studies have indicated that many factors, such as the growth rate, water quality, and capture pressure of fishing activity influence the size of the early mature gonads (de Graaf et al. 2003; Moresco and Bemvenuti 2006; Laleye et al. 2006).

Female broodstock fecundity varies between species and within the same species as a result of adaptation to habitats. The striped eel catfish fecundity in the Kolono Bay ranges from 1,415 to 2,194 eggs, with an average of $1,730 \pm 390$ eggs. This number is higher than that in the striped eel catfish in the waters of the North Andhra Pradesh coast, India, which ranges from 913 to 2,298 eggs, with an average of $1.558 \pm 349$ eggs (Vijayakumaran 1997), and in the waters of the Sungsan and Jocheon coast, Korea, which ranges from 525 to 1,176 eggs (Heo et al. 2007). The variation might occurred due to the environmental conditions of $P$. lineatus. The variation in the amount of fecundity is the mechanism and strategy of fish to increase the number of eggs and fish growth rates (Duarte and Araújo 2002). Several factors can vary the fecundity, such as season, food, habitat and aquatic environment, the diameter of the eggs, and differences in fish age (Nikolsky 1963; Suzuki et al. 2000; Saliu and Fagade 2003). Even in population stock, fecundity varies and is comparable to fish size and condition. This condition happened in striped eel catfish, whose size is more extended, and have higher fecundity than smaller fish. The latter results appeared from the model of the relationship between fecundity and the total length of striped eel catfish $\left(\mathrm{R}^{2}=0.61\right)$. Such model can be used to predict the amount of fecundity generated in a population. A similar situation was reported for $P$. canius in the Khulna coast, Bangladesh (Khan et al. 2002) and $P$. lineatus in the waters of the Sungsan and Jocheon coast, Korea (Heo et al. 2007) and other catfish, such as Mystus gulio in the Khulna, Bangladesh (Islam et al. 2008) and Pelteobagrus spp. in the Gorges Reservoir, China (Liao et al. 2018). However, the association between fecundity and weight mass cannot be used as a prediction model. They are determining the amount of fecundity because it has a coefficient of determination $<50 \%\left(\mathrm{R}^{2}=0.33\right)$. The low coefficient of determination of the model was also found in species $P$. canius (Usman et al. 2013b).

Egg diameter varies between species and among individuals within the same species. The size of the egg diameter increases with the gonad maturity and GSI (Figure 5). Striped eel catfish eggs are about 0.11-1.35-mm which was smaller than the egg diameters of other catfish groups such as Loricariichthys castaneus (Gomes et al. 2011) and P. canius (Usman et al. 2013b; Amornsakun et al. 2018). The factor that possibly influences the variations in egg diameter is the nature of caregiving, population density, and environmental conditions (Shinkafi and Ipinjolu 2012; Usman et al. 2013b; Barneche et al. 2018). The distribution of egg diameters has one mode, indicating that striped eel catfish release their eggs simultaneously during the spawning season. This result is in line with the behavior of $P$. lineatus in the northern waters of the Andhra Pradesh coast, India (Vijayakumaran, 1997), and the Sungsan and Jocheon coast, Korea (Heo et al. 2007). Striped eel catfish were grouped as synchronous groups (Murua and Sabarido-Rey 2003) or known as spawners in unison (total spawner). Siluriformes (catfish) spawning patterns do not always spawn simultaneously, but there are partial spawners, such as Loricariichthys platymetopon, Loricariichthys sp., Loricaria sp. (Suzuki et al. 2000); and P. canius (Usman et al. 2013b; Amornsakun et al. 2018).

In present study, the highest proportion of gonad development was found during the spent/spawning stage $(60 \%$ and $55.56 \%)$ and the GSI peak values for male and female fish $(1.19 \pm 0.532$ and $19 \pm 3.47$, respectively) were noted during the East season (June-August), and such results can be used as a guide to predict the spawning time of striped eel catfish. This information can be used as one of the policy bases for spawning ground protection in Kolono Bay to provide these fish with the opportunity to spawn at least once before being caught. The size of the first mature gonad at $198.3 \mathrm{~mm}$ suggests that striped eel catfish above this size can be caught to ensure the sustainability of its population in nature. Regular observation of the size at first mature gonad can be an indicator of pressure on the population. Reproductive capacity produced in the striped eel catfish conservation had some factors. They are the value of fecundity $(1,730 \pm$ 390 eggs), the amount of fecundity based on total body length $\left(\mathrm{R}^{2}=0.61\right)$, and spawning patterns (total spawner). It is important to acquire data on their reproductive habits to manage resources and conserve striped eel catfish.

\section{ACKNOWLEDGEMENTS}

The authors would like to thank Exfar Alli Ridwan, Risko Arsyad, La Asrin, Rines Andani, and undergraduate students of the Faculty of Fisheries and Marine Sciences of Halu Oleo University (La Aha and Sasri Sulastri) for their assistance in collecting data in the field; Faculty of Fisheries and Marine Sciences, the Halu Oleo University, Kendari, Indonesia for all the support of the facilities in 
completing this research. This research was supported by Ministry of Research and Technology/Research and Innovation Agency of the Republic of Indonesia (Grant number: 131/SP2H/AMD/LT/DRPM/2020 and 026/SP2H/ LT/DRPM/2021).

\section{REFERENCES}

Adebiyi FA, Siraj SS, Harmin SA, Christianus A. 2011. Ovarium development of a river catfish Hemibagrus nemurus (Valenciennes, 1840) in captivity. J Exp Zool A Ecol Genet Physiol 315 (9): 536543. DOI: $10.1002 /$ jez.702

Ahmed SU, Haque A. 2007. Studies on the fishery, biology, and domestication of gang magur, Plotosus canius. BFRI Annual Progress Report 6. Bangladesh Fisheries Research Institute, Bangladesh.

Alp A, Kara C. 2007. Distribution pattern and morphological differences between the sexes of River Blenny, Salaria fluviatilis (Asso,1801) in the Ceyhan River Basin, Turkey. Turk J Vet Anim Sci 31: 113-120.

Amornsakun T, Krisornpornsan B, Jirasatian P, Pholrat T, Pau TM, bin Hassan A. 2018. Some reproductive biological aspects of gray-ee catfish, Plotosus canius Hamilton, 1822 spawner in Pattani Bay, Thailand. Songklanakarin J Sci Technol 40 (2): 384-389. DOI:10.14456/sjst-psu.2018.59.

Araújo FG, Nascimento AA, Gomes ID, Sales A, de Oliveira BAC. 2019. Gonadal development and reproductive period of the characin Astyanax aff. bimaculatus (Characiformes: Characidae) in a tropical reservoir in southeastern Brazil. Zoologia 36: 1-14. DOI: 10.3897/zoologia.36.e30610.

Arula T, Shpilev H, Raid T, Sepp E. 2019. Thermal conditions and age structure determine the spawning regularities and condition of Baltic herring (Clupea harengus Membras) in the NE of the Baltic Sea. Peer J 7: e7345. DOI: $10.7717 /$ peerj.7345.

Asriyana, Irawati N, Indrayani. 2018. Trophic ecology of two blotch ponyfish Nuchequula blochii in Kendari Bay, Southeast Sulawesi, Indonesia. AACL Bioflux 11 (1): 66-82.

Asriyana, Irawati N. 2019. Assessment of the trophic status in Kendari Bay, Indonesia: a case study. AACL Bioflux 12 (2): 650-663.

Asriyana A, Halili H, Irawati N. 2020a. Size structure and growth parameters of striped eel catfish (Plotosus lineatus) in Kolono Bay, Southeast Sulawesi, Indonesia. AACL Bioflux 13 (1): 268-279.

Asriyana A, Irawati N, Halili H. 2020b. Length-weight relationships and ponderal index of three reef fish (Teleostei: Labridae) off the Tanjung Tiram coast, Southeast Sulawesi, Indonesia. Biodiversitas 21 (4) 1279-1286. DOI: $10.13057 /$ biodiv/d210402

Asriyana A, Halili H. 2021. Diversity of Mullidae as by-catch of Plotosidae fishery in the waters of Southeast Sulawesi, Indonesia. AACL Bioflux 14 (2): 621-634.

Ball DV, Rao KV. 1984. Marine Fisheries of India. McGraw-Hill Publishing Company Ltd. NewDelhi. 470 p.

Barbosa TAP, Rosa DCO, Soares BE, Costa CHA, Esposito MC, Montag LFA. 2018. Effect of flood pulses on the trophic ecology of four piscivorous fishes from the eastern Amazon. J Fish Biol 93: 30-39. DOI: $10.1111 /$ jfb. 13669

Barneche DR, Burgess SC, Marshall DJ. 2018. Global environmental drivers of marine fish egg size. Glob Ecol Biogeogr 27 (8): 890-898 DOI: $10.1111 /$ geb. 12748

De Graaf M, Machiels M, Wudneth T, Sibbing FA. 2003. Length at maturity and gillnet selectivity of Lake Tana's Barbus species (Ethiopia): Implication for management and conservation. Aquat Ecosyst Health Manag 6 (3): 325-3. DOI: 10.1080/14634980301485.

Dewanti YR, Irwani, Rejeki S. 2012. Reproductive and morphometry study of gray eel-catfish (Plotosus canius) in the Krobokan Region of Semarang. J Mar Res 1 (2): 135-144. [Indonesian]

Doğdu SA, Uyan A, Uygur N, Gürlek M, Ergüden D, Turan C. 2016. First record of the Indo-Pacific striped eel catfish, Plotosus lineatus (Thunberg, 1787) from Turkish marine waters. Natural Eng'g Sci 1 (2): $25-32$.

Duarte S, Araújo FG. 2002. Fecundity of the Hypostomus affinis (Siluriformes, Loricariidae) in the Lajes Reservoir, Rio de Janeiro, Brazil. Rev Biol Trop 50 (1): 193-197.

Freitas TMS, Montag LFA. 2019. Population and reproductive parameters of the red-tailed catfish, Phractocephalus hemioliopterus
(Pimelodidae: Siluriformes), from the Xingu River, Brazil. Neotrop Ichthyol 17 (2): e190015. DOI: 10.1590/1982-0224-20190015.

Froese R, Pauly D, editors. 2020. FishBase [database on the Internet]. World Wide Web electronic publication; [cited 2020 June 12]. Available from: www.fishbase.org.

Galanidi M, Turan C, Öztürk B, Zenetos A. 2019. Europen Union (EU) Risk assessment of Plotosus lineatus (Thunberg, 1787); a summary and information update. J Black Sea/Medit Environ 25 (2): 210-231.

Gallagher CP, Howland KL, Sandstrom SJ, Halden NM. 2018. Migration tactics affect spawning frequency in an iteroparous salmonid (Salvelinus malma) from the Arctic. PLoS ONE 13 (12): e0210202. DOI: 10.1371/journal.pone.0210202.

Gomes ID, Araújo FG, Uehara W, Sales A. 2011. Reproductive biology of the armoured catfish Loricariichthys castaneus (Castelnau, 1855) in Lajes reservoir, southeastern Brazil. J Appl Ichthyol 27 (6): 13221331. DOI: 10.1111/j.1439-0426.2011.01874.x.

Gomon JR. 1984. Plotosidae. In: Fischer W, Bianchi G, editors. FAO Species Identification Sheets for Fishery Purposes (Volume 3). Western Indian Ocean fishing area 51. FAO Fisheries Department, Rome.

Harvey BJ, Hoar WS. 1979. The Theory and Practice of Induced Breeding in Fish. International Development Research Centre, Ottawa, Canada.

Heo SI, Ryu YW, Rho S, Lee CH, Lee YD. 2007. Reproductive cycle of the striped eel catfish Plotosus lineatus (Thunberg). J Korean Fish Soc 40: 141-146. [Korean]

Ilhan DU, Togulga M. 2007. Age, growth and reproduction of tub gurnard Chelidonichthys lucernus Linn. 1758 (Osteichthtyes: Triglidae) from Izmir Bay, Aegean Sea, Eastern Mediterraean. Acta Adriat 48 (2): 173-184.

Islam MA, Begum M, Pal HK, Alam MJ. 2008. Studies on the gonadosomatic index and fecundity of Mystus gulio (Ham.). Progress Agric 19 (2): 161-166. DOI: 10.3329/pa.v19i2.16957.

IUCN Bangladesh. 2000. Red Book of Threatened Fishes of Bangladesh. IUCN-The World Conservation Union, Bangladesh.

Jobling M. 1995. Environmental Biology of Fishes. Chapman and Hall. London.

Khan MSA, Alam, MJ, Rhema S, Mondol S, Rahman MM. 2002. Study on the fecundity and GSI of brackish water catfish Plotosus canius (Hamilton-Buchanan). J Biol Sci 2 (4): 232-234.

King M. 1995. Fisheries Biology, Assessment, and Management. Fishing News. London.

Lagler KF, Bardach JE, Miller RH, Passino DM. 1977. Ichthyology. John Willey \& Sons Inc., Toronto, Canada

Laleye P, Chikou A, Gnohossou P, Vandewalle P, Philippart JC, Teugels G. 2006. Studies on the biology of two species of catfish Synodontis schall and Synodontis nigrita (Ostariophysi: Mochokidae) from the Ouèmè River, Bènim. Belg J Zool 136 (2): 193-201.

Le Cren ED. 1951 The length-weight relationship and seasonal cycle in gonad weight and condition in the perch Perca fluviatilis. J Anim Ecol 20 (2): 201- 219. DOI: 10.2307/1540.

Liang SH, Wu HP, Shieh BS. 2005. Size structure, reproductive phenology, and sex ratio of an exotic armored catfish (Liposarcus multiradiatus) in the Kaoping River of southern Taiwan. Zool Stud 44: 252-259.

Liao C, Chen S, Guo Z, Ye S, Zhang T, Li Z, Murphy BR, Liu J. 2018. Species-specific variations in reproductive traits of three yellow catfish species (Pelteobagrus spp.) in relation to habitats in the Three Gorges Reservoir, China. PLoS ONE. 13 (7): e0199990. DOI: 10.1371/journal. pone.0199990.

Lizama MAP, Ambrósio AM. 2002 Condition factor in nine species of fish of the Characidae family in the upper Paraná River floodplain, Brazil. Braz J Biol 62 (1): 113-124. DOI: 10.1590/s151969842002000100014

Moresco A, Bemvenuti de A. 2006. Reproductive biology of silverside Odontesthes argentinensis (Valenciennes) (Atherinopsidae) of coastal sea region of the south of Brazil. Rev Bras Zool 23 (4): 1168-1174. DOI: 10.1590/S0101-81752006000400025.

Murua H, Sabarido-Rey F. 2003. Female reproductive strategies of marine fish species of the North Atlantic. J Northw Atl Fish Sci 33: 23-31. DOI: $10.2960 /$ J.v33.a2.

Myers RF. 1991. Micronesian reef fishes. Second Ed. Coral Graphics, Barrigada, Guam. 298 p.

Nikolsky GV. 1963. The Ecology of Fishes. Academic Press. New York.

Offem BO, Ayotunde EO, Ikpi GU. 2008. Dynamics in the reproductive of Heterobranchus longifilis Val. (Pisces: 1840) in the wetlands of Cross River, Nigeria. Res J Fish Hydrobiol 3 (1): 22-31. 
Patra MK, Acharjee SK, Chakraborty SK. 2005. Conservation categories of siluroid fishes in North-East Sundarbans, India. Biodivers Conserv 14 (8): 1863-1876.

Saliu KS, Fagade SO. 2003. The reproductive biology of Brycinus nurse (Paugy, 1986) Characidae in Asa Reservoir, Ilorin, Nigeria. Turk J Fish Aquat Sc 3: 5-9. DOI: 10.1007/s10641-006-9053-0.

Shinkafi BA, Ipinjolu JK. 2012. Gonado somatic index, fecundity and egg size of Auchenoglanis occidentalis (Cuvier and Valenciennes) in River Rima, North-Western Nigeria. Nig J Basic Appl Sci 20 (3): 217-224.

Sinha M. 1984. Sex ratio, size at first maturity and fecundity of the canine catfish-eel, Plotosus canius Hamilton. Indian J Anim Sci 54 (12) 1151-1158.

Sokal RR, Rohlf FJ. 1995. Biometry: The Principles and Practice of Statistics in Biological Research. 3rd edition. WH Freeman and Co., New York.

Suzuki HIS, Agostinho AA, Winemiller KO. 2000. Relationship between oocyte morphology and reproductive strategy in loricariid catfishes of the Parana' River, Brazil. J Fish Biol 57: 791-807. DOI: 10.1006/jfbi.2000.1352.

Taylor WR, Gomon JR. 1986. Plotosidae. In Daget J, Gosse JP and Thys van den Audenaerde DFW (eds.) Check-list of the freshwater fishes of Africa (CLOFFA). Vol. 2. ISBN, Brussels; MRAC, Tervuren; and ORSTOM, Paris.

Teixeira GE, Bialetzki A, Soares BE, Souza G, Caramaschi EP. 2019. Variation in the structure of the ichthyoplankton community in the lower Paraíba do Sul River. Neotrop Ichthyol 17 (4): e180004. DOI: 10.1590/1982-0224-20180004.

Thu PT, Huang W-C, Chou T-K, Van Quan N, Van Chien P, Li F, Shao $\mathrm{K}$, Liao T. 2019. DNA barcoding of coastal ray-finned fishes in Vietnam. PLoS ONE 14 (9): e0222631. DOI: 10.1371/journal. pone.0222631.

Trueman WT. 2006. Methods for the Hatchery Production of the Freshwater Jewfish or Eel Tailed Catfish, Tandanus tandanus. Native Fish Australia Inc., Australia.
Türkmen M, Erdogan O, Ayhan Y, Akyurt I. 2002. Reproduction tactics, age and growth of Capoeta capoeta umbla Heckel 1843 from the AsËkale Region of the Karasu River, Turkey. Fish Res 54: 317-328.

Tzikas Z, Ambrosiadis I, Soultos N, Georgakis S. 2007. Seasonal size distribution, condition status and muscle yield of Mediterranean horse mackerel Trachurus mediterraneus from the North Aegean Sea, Greece. Fish Sci 73 (2): 453-462. DOI: 10.1111/j.14442906.2007.01354.x.

Usman BI, Amin SMN, Arshad A, Rahman MA. 2013a. Review of some biological aspects and fisheries of grey-eel catfish Plotosus canius (Hamilton, 1822). Asian J Ani Vet Adv 8 (2): 154-167. DOI: 10.3923/ajava.2013.154.167.

Usman BI, Amin SMN, Arshad A, Rahman MA. 2013b. Fecundity and egg size of grey-eel catfish Plotosus canius (Hamilton, 1822) from the Coastal Waters of Kampong Telok, Negeri Sembilan Peninsular Malaysia. Asian J Anim Vet Adv 8 (2): 348-354. DOI: 10.3923/ajava.2013.348.354.

Verweij MC, Nagelkerken I, de Graaff D, Peeters M, Bakker EJ, van der Velde G. 2006. Structure, food and shade attract juvenile coral reef fish to mangrove and seagrass habitats: a field experiment. Mar Ecol Prog Ser 306: 257-268. DOI: 10.3354/meps306257.

Vicentini RN, Araújo FG. 2003. Sex ratio and size structure of Micropogonias furnieri (Desmarest, 1823) (Perciformes, Sciaenidae) in Sepetiba Bay, Rio de Janeiro, Brazil. Braz J Biol 63 (4): 559-566. DOI: $10.1590 / \mathrm{S} 1519-69842003000400003$.

Vijayakumaran K. 1997. Growth and mortality parameters and some aspects of biology of striped eel catfish Plotosus lineatus (Thunberg) from north Andhra Pradesh coast. J Mar Biol Assoc India 39 (1-2): 108-112.

Ya NA, Singh HR, Samat A, Mohd Rashid HN, Ramli NH, Makhtar N, Dzakaria N. 2015. Length-weight relationship of six fish species from Sepang Besar River Estuary, Malaysia. J Adv Res Appl Sci Eng Technol 1 (1): 27-35.

Yoneda M, Wright PJ. 2005. Effect of temperature and food availability on reproductive investment of first-time spawning male Atlantic cod, Gadus morhua. ICES J Mar Sci 62: 1387e1393. DOI: 10.1016/j.icesjms.2005.04.018. 